Etnográfica

Revista do Centro em Rede de Investigação em

Antropologia

vol. $20(3) \mid 2016$

Vol. 20 (3)

\title{
Chimpanzee politics: some personal reflections on in situ primate conservation in Africa
}

Política de chimpanzés: algumas reflexões pessoais sobre conservação de primatas in situ em África

\section{Spartaco Gippoliti}

\section{(2) OpenEdition}

\section{Journals}

Electronic version

URL: https://journals.openedition.org/etnografica/4778

DOI: 10.4000/etnografica. 4778

ISSN: 2182-2891

\section{Publisher}

Centro em Rede de Investigação em Antropologia

\section{Printed version}

Date of publication: 1 October 2016

Number of pages: 672-675

ISSN: 0873-6561

\section{Electronic reference}

Spartaco Gippoliti, "Chimpanzee politics: some personal reflections on in situ primate conservation in Africa", Etnográfica [Online], vol. 20 (3) | 2016, Online since 28 November 2016, connection on 10 February 2022. URL: http://journals.openedition.org/etnografica/4778 ; DOI: https://doi.org/10.4000/ etnografica. 4778

\section{(c) (7) (5)}

Etnográfica is licensed under a Creative Commons Attribution-NonCommercial 4.0 International License. 


\title{
Chimpanzee politics: some personal reflections on in situ primate conservation in Africa
}

\section{Spartaco Gippoliti}

\begin{abstract}
This paper discusses the importance of western influence and perceptions on the conservation of nonhuman primates and other biodiversity, and the need for an ethical approach to conservation that is centred in the involvement of the local population, a vision shared by Cláudia Sousa.

KEYWORDS: biodiversity conservation, primates, ethics, parks, local culture.

Política de chimpanzés: algumas reflexões pessoais sobre conservação de primatas in situ em África - Esta comunicação discute a importância das perceções ocidentais e a sua influência na conservação de primatas não humanos e da biodiversidade, bem como a necessidade de uma abordagem ética da conservação centrada no envolvimento das populações locais, visão partilhada por Cláudia Sousa.

PALAVRAS-CHAVE: conservação da biodiversidade, primatas, ética, parques, cultura local.
\end{abstract}

GIPPOLITI, Spartaco (spartacolobus@hotmail.com) - IUCN/SSC Primate Specialist Group; Safari Ravenna Zoological Park, Italy.

CONSERVATION EFFORTS WILL ONLY SUCCEED IF THE CONSERVATION and scientific communities demand an ethical approach to biodiversity conservation. For example, the conservation efforts for single species are often justified by their beauty, intelligence, physical similarities to humans, but can such attitudes remain successful in the long term? Human preference to conserve certain large-bodied animals is paradoxical if we consider that "wild" habitats are shrinking and become increasingly isolated, and thus threaten the viability of large-sized animal populations. Some large-bodied species, such as the chimpanzee (Pan troglodytes), exhibit predatory behaviour toward other species, such as red colobus monkeys (Piliocolobus spp.) (Watts and Amsler 2013), which might also be threatened locally with extinction. This casts doubt regarding claims that species such as the chimpanzee always act as important "umbrella" species (defined as species with large area requirements, which if given sufficient protected habitat area will bring many other species under protection; Caro 2003) for biodiversity conservation in African forest fragments (Gippoliti and Sousa 2004). Furthermore, a reliance on protected areas to 
ensure biodiversity conservation poses several ethics issues related to the treatment of local human populations, some of which have used these areas to access resources for generations and have now had restrictions imposed on them. To acknowledge the importance of the ethical treatment of local people, as well as the wildlife, a protocol could be established so that field researchers include an ethics statement at the end of research papers, such as "the research has been carried out in a protected area that adopts a fair policy toward local communities", much in the same way that behavioural research on wildlife requires an ethics statement.

The idea of national parks was born in the United States and spread quickly across the world. However, it is rarely acknowledged that the ways in which national parks were established and managed differed geographically. In Europe people were generally involved in management decisions and continued to reside within the parks. In colonial territories or newly established nations (such as the US, Canada and Australia), people were generally not allowed inside national parks and native populations were forcibly transferred to other areas. This was the case in 1879 with the Shoshone tribes in the Yellowstone National Park, the first ever national park, funded in 1872 (Vernizzi 2011). This model was then exported to Africa, and especially applied to British East Africa (Neumann 1996). The approach continues today, with some international bodies considering protected areas as a major threat to the survival of ethnic minorities throughout the world (Survival International 2014; see also Agrawal and Redford 2009).

This leads us, as primatologists and anthropologists, to an obvious paradox. We study human's closest living relatives and fight to conserve them in their natural habitat, but often forget the rights and needs of our fellow human beings that frequently live below the poverty line (but see Shiva 1988 for a discussion about the meaning of poverty and misery). Some acts by local people are today perceived very negatively in our western "urbanized" world. For example, there is public outrage, especially in more economically developed countries surrounding the so-called bushmeat crisis, especially in Africa, where human prey includes gorillas (Gorilla spp.), chimpanzees and elephants (Loxodonta cyclotis) among other highly visible and charismatic species. Much less concern is expressed towards infrastructures (dams, highways) or industrial large-scale plantations (oil palm and cacao, for example) that are probably seen as "unavoidable" from an "industrialized" perspective.

Obviously, no single conservation model can be applied successfully everywhere. In very critical situations (high human density, frequent hunting), such as in the few remaining high forest areas in Upper Guinea, the fortress paradigm to protected area management may still be the only option. Even in this case, however, we should pay attention to local communities and be careful in utilizing "environmental universalism" to justify conservation. Especially 
when foreign NGOs are involved, it should be clear to everybody that emphasis should be put on ecosystem services that benefit local communities, rather than wildlife, that may have a high appeal in London or Milan but are seen as a nuisance by local people. Conservationists and primatologists must be aware that conservation programs that fail to include a strong human component can do more harm than good, as "some conservation programs are likely to create anger and bitterness", resulting in that local residents could "have strong incentives to destroy the wildlife and resources within protected areas" (Agrawal and Redford 2009: 6).

\section{GUINEA-BISSAU: A NEW MODEL FOR CHIMPANZEE CONSERVATION IN HUMAN-DOMINATED LANDSCAPES?}

In the last decade of the XX century very little was known concerning the conservation status and socio-ecology of the West African chimpanzee, although Pan troglodytes verus was already considered the most threatened chimpanzee subspecies (Lee, Thornback and Bennett 1988). So our preliminary survey of primates in Guinea-Bissau (Gippoliti and Dell'Omo 1996) was an attempt to balance the biased research attention directed towards East African chimpanzees and, generally, towards wildlife conservation in the former British colonies of Kenya and Tanzania. The wildlife and landscape in these two countries generate an enormous income from tourism following a well-known trend established from the time of Karen Blixen's Out of Africa. Yet, if you believe that biodiversity conservation not only concerns personal moral or aesthetic visions, but also the welfare and future well-being of humanity (Papa Francesco 2015), such initiatives must be attempted even in the poorest countries in the world. In the specific case of Guinea-Bissau, we find a general attitude which is favourable to chimpanzees (Gippoliti and Dell'Omo 1996; Gippoliti, Embalo and Sousa 2003; Sousa and Frazão-Moreira 2010; Hockings and Sousa 2012). For conservation to have the best chance of success, it is beneficial to work with local arguments and beliefs that are strongly imbedded in the local culture rather than attempting to force foreign conservation ethics.

In this respect, over the last decade primatological research in GuineaBissau has produced a wealth of information regarding local people's relationships with other great apes, other primates, and nature, much of which can be attributed to the vision and dedication of Cláudia Sousa. ${ }^{1}$

I Although nonhuman animals have always played a special role in my life, I have been lucky enough to meet a few very special individuals of my own species. One of them is Giacomo Dell'Omo, who has been the ideal companion of fieldwork in Guinea-Bissau in 1994. In 2002 I met Cláudia Sousa in Guinea-Bissau, visiting several potential fieldwork sites in Cantanhez Forest, Lagoa de Cufada and Boé. I soon realized that Cláudia had all the skills to be an excellent fieldworker and project coordinator. She fully deserves to be recognized among the founders of primatology in Portugal and Guinea-Bissau. 


\section{REFERENCES}

AGRAWAL, Arun, and Kent REDFORD, 2009, "Conservation and displacement: an overview", Conservation and Society, 7: 1-10.

CARO, Tim, 2003, "Umbrella species: critique and lessons from East Africa", Animal Conservation, 6: 171-181.

GIPPOLITI, Spartaco, and Giacomo DELl'OMO, 1996, "Primates of the Cantanhez Forest and the Cacine Basin, Guinea-Bissau", Oryx, 39: 74-80.

GIPPOLITI, Spartaco, and Cláudia SOUSA, 2004, "Chimpanzee Pan troglodytes as an 'umbrella' species for conservation in Guinea-Bissau: opportunities and constrains", Folia Primatologica, 75: 386.

GIPPOLITI, Spartaco, Daniel S. EMBALO, and Cláudia SOUSA, 2003, "Guinea-Bissau”, in Rebecca Kormos, Christophe Boesch, Mohamed I. Bakarr and Thomas M. Butynsk (eds.), West African Chimpanzees: Status Survey and Conservation Action Plan. Gland, IUCN Publication, Switzerland, 55-61.

HOCKINGS, Kim J., and Cláudia SOUSA, 2012, "Differential utilization of cashew - a low conflict crop - by sympatric humans and chimpanzees”, Oryx, 46: 375-381.

LEE, Phyllis C., Jane THORNBACK, and Elisabeth L. BENNETT, 1988, Threatened Primates of Africa, The IUCN Red Data Book. Gland, IUCN Publication.

NEUMANN, Roderick P., 1996, "Dukes, earls and ersatz edens: aristocratic nature preservationist in colonial Africa", Environment and Planning D: Society and Space, 14: 99-122.

PAPA FRANCESCO, 2015, Laudato Sì. Vatican City, Tipografia Vaticana.

SHIVA, Vandana, 1988, Staying Alive: Women, Ecology and Survival in India. London, Zed Books.

SOUSA, Cláudia, and Amélia FRAZÃO-MOREIRA, 2010, "Etnoprimatologia ao serviço da conservação na Guiné-Bissau: o chimpanzé como exemplo”, in Ângelo Giuseppe Chaves Alves, Francisco José Bezerra Souto and Nivaldo Peroni (eds.), Etnoecologia em Perspectiva: Natureza, Cultura e Conservação. Recife, NUPEEA, 189-200.

SURVIVAL INTERNATIONAL, 2014, Parks Need Peoples, London, Survival International UK. VERNIZZI, Emily A., 201 1, The Establishment of the United States National Parks and the Eviction of Indigenous People, Senior Project. San Luis Obispo, CA, California Polytechnic State University.

WATTS, David, and Sylvia J. AMSLER, 2013, "Chimpanzee-red colobus encounter rate show a red colobus population decline associate with predation by chimpanzees at Ngogo", American Journal of Primatology, 75: 927-937. 